Einstein and Soviet Ideology 


\section{Stanford Nuclear Age Series}

General Editor, Martin Sherwin

A DVISORY BOARD

Barton J. Bernstein, David Holloway, and Wolfgang K. H. Panofsky 


\section{ALEXANDER VUCINICH \\ Einstein and Soviet Ideology}

Stanford University Press, Stanford, California 
Stanford University Press

Stanford, California

(C) 2001 by the Board of Trustees of the

Leland Stanford Junior University

Library of Congress Cataloging-in-Publication Data

Vucinich, Alexander.

Einstein and Soviet ideology / Alexander Vucinich.

p. $\mathrm{cm}$. - (Stanford nuclear age series)

Includes bibliographical references and index.

ISBN 0-8047-4209-X (alk. paper)

1. Communism and science-Soviet Union-History. 2. Communism and science. 3. Soviet Union-Politics and government. 4. Einstein, Albert, 1879-1955. I. Title. II. Series.

HX514.V83 2001

$530^{\prime} .0947^{\prime} 0904-\mathrm{dc21}$

2001032266

This book is printed on acid-free, archival-quality paper.

Original printing 2001

Last figure below indicates year of this printing:

$\begin{array}{llllllllll}10 & 09 & 08 & 07 & 06 & 05 & 04 & 03 & 02 & 01\end{array}$

Typeset in 10/12.5 Minion 
To Reginald E. Zelnik 
